\title{
Fen Bilgisi Öğretmen Adaylarının Lisansüstü Eğitime Yönelik Tutumlarının incelenmesi* $^{*}$
}

\section{Investigation of Preservice Science Teachers' Attitudes towards Graduate Education}

\begin{abstract}
Meryem DEMiR $^{* *}$
Öz. Bu çalışmanın amacı, fen bilgisi öğretmen adaylarının lisansüstü eğitime iliş̧kin tutumlarının cinsiyet, mezun olunan lise türü, aile gelir durumu, sınıf düzeyi, anne ve babanın öğrenim durumu değişkenleri açısından incelenmesidir. Çalışmanın örneklemini 2016-2017 akademik yılında iki farklı devlet üniversitesinden uygun örnekleme yöntemi ile seçilmiş Fen Bilgisi Eğitimi Ana Bilim Dalı'nda öğrenim görmekte olan 201 kadın, 34 erkek olmak üzere toplam 235 fen bilgisi öğretmen adayı oluşturmaktadır. Çalışmanın örnekleminin belirlenmesinde uygun örnekleme yöntemi kullanılmıştır. Çalışmada nicel araştırma yöntemlerinden tarama yöntemi kullanılmıştır. Araştırmada veri toplama aracı olarak 30 maddeden oluşan Lisansüstü Eğitime İlişkin Tutum Ölçeği (İzgi, 2016) kullanılmıştır. Araştırma verileri kişisel bilgi formunun ve lisansüstü eğitime yönelik tutum ölçeğinin fen bilgisi öğretmen adaylarına uygulanması sonucunda toplanmıştır. İstatistiksel analizler uygulanmış ve bulgulara ulaşılmıştır. Araştırma sonucunda fen bilgisi öğretmen adaylarının lisansüstü eğitime yönelik tutumlarının yüksek olduğu görülmüştür. Araştırılan değişkenler arasında anlamlı farklılık görülmemiştir.
\end{abstract}

Anahtar Kelimeler: Lisansüstü eğitim, öğretmen adayları, tutum.

\begin{abstract}
The number of individuals conducting undergraduate education in our country is increasing day by day, and some of the individuals who have completed undergraduate education tend to have graduate education. A lot of factors can be attributed to this tendency. In this regard, the purpose of this research is to analyze the attitudes of preservice science teachers towards graduate education based on their gender, high school types, socioeconomic levels of their families, class levels, and the educational status of their parents. The sample of this research is composed of 201 female, 34 males, and in total, 235 preservice science teachers from two different public universities in the 2016-2017 academic year. Convenient sampling method was used in determining the sample of the study. In this research, survey method was used from quantitave research methods. In the research, attitudes towards higher education scale, which was developed by Izgi (2016), was used as a data collection tool. The data collection tool has 30 questions, and consists of questions related to personal infromation and attitudes towards-graduate education scale. Research data was collected by a demographic questionnaire, and attitudes towards graduate education scales which were applied to preservice science teachers. Statistical analysis was carried out to obtain the results. The search has showed that attitudes of preservice science teachers towards graduate education are quite high. No significant difference was found between the variables studied.
\end{abstract}

Keywords: Graduate education, candidate teachers, attitude.

\section{Toplumsal Mesaj.}

$\mathrm{Bu}$ çalışmada fen bilgisi öğretmen adaylarının lisansüstü eğitime ilişkin tutumlarının bazı değişkenler açısından incelenmes amaçlanmıştır. Çalışmanın sonucunda fen bilgisi öğretmen adaylarının lisansüstü eğitime yönelik tutumlarının yüksek düzeyde olduğu görülmüştür. Fen bilgisi öğretmen adaylarının lisansütü eğitime yönelik tutumlarının sınıf düzeyi, lise türü, cinsiyet, aylık gelir durumu, ebeveynlerin öğrenim durumu değişkenlerine göre farklılık göstermediği sonucuna varılmıştır.

\section{Public Interest Statement.}

In this regard, the purpose of this research is to analyze the attitudes of candidate science teachers towards graduate education based on their gender, high school types, socioeconomic levels of their families, class levels, and the educational status of their parents. As a result of the study, it has been seen that the attidues of the science teachers towards the graduate education are high.

\footnotetext{
* Bu çalışma VIII. Uluslararası Lisansüstü Eğitim Sempozyumunda bildiri olarak sunulmuştur.

${ }^{* *}$ Sakarya Üniversitesi, Eğitim Bilimleri Enstitüsü, Fen Bilgisi Eğitimi Bilim Dalı, meryemdmir@gmail.com

${ }^{* * \star}$ Doç, Dr., Sakarya Üniversitesi, Eğitim Fakültesi, Matematik ve Fen Eğitimi Anabilim Dalı, sbesoluk@sakarya.edu.tr
} 


\section{GíRiş}

Eğitim kurumlarının ve öğretmen yetiştirmenin toplumların ilerleyişindeki önemi yadsınamaz. Tarihsel gelişim içinde Türkiye'de öğretmenler, ortaöğretim düzeyinden önlisans, lisans ve lisansüstü düzeye değin farklı düzeylerde eğitim alarak yetiştirilmiştir (Okçabol, 2005). Öğretmen yetiştirmede üniversitelerin yadsınamaz bir önemi vardır. Güven ve Tunç (2007: 158) tarih boyunca, toplumda üniversitelere farklı işlevler yüklendiğini ve tüm dönemlerde üniversitenin işlevlerinin "öğretim yapmak, araştırma yapmak ve yüksek nitelikli insan gücünü yetiştirmek" şeklinde sınıflandırıldığını belirtmiştir. Bilginin geliştirilmesi ve üretiminde, lisansüstü çalışmalar için yapılan araştırma faaliyetlerinin katkısı önemlidir. Lisansüstü eğitim çeşitli tanımlar ile açıklanmış ve önemine ilişkin çeşitli saptamalar yapılmıştır. Oğuzkan'a (1981) göre, lisansüstü eğitim, lisans derecesi ya da diploması almış olanlara ilgi duydukları bir bilim dalında yüksek lisans, bilim uzmanlığı ya da doktora öğrenimi yaparak uzmanlaşma olanağı sağlamak üzere düzenlenen eğitim olarak tanımlanmaktadır. Lisansüstü eğitim; lisans eğitimine dayalı olan yüksek lisans ve doktora eğitimi ile sanat dallarında yapılan sanatta yeterlilik çalışması ve tıpta uzmanlık ile bunların gerektirdiği öğretim, bilimsel araştırma ve uygulama etkinliklerinden oluşan eğitim olarak tanımlanmaktadır (YÖK, 2016). Varış'a (1972) göre, lisansüstü eğitim; üniversitede lisansüstü derecelere götüren, araştırma yoluyla bilgiye katkıda bulunacak ve gelişen toplumun ihtiyaçlarını karşılayacak bilim insanı ve öğretim elemanı yetiştirmeyi amaç edinen bir faaliyet olarak tanımlanmaktadır. Yine Çakar (1997), lisansüstü eğitimi, bir alanda derinlemesine çalışarak lisans eğitiminde daha üst seviyede bilgi ve etkinliğe sahip olan yüksek ihtisas gücünü yetiştiren eğitim programı olarak tanımlamışır. Nitekim verilen bu programlar bireylerin mesleki alanında donanımlarını artırmak, akademik derinleşmesini sağlamak ve ilgili iş alanlarında gerekli nitelikli elemanları yetiştirmek amacındadır. Bu bağlamda Yüksek lisansın, bilginin üretimi ve geliştirilmesindeki faydalarının yanı sıra, çalışılan alana ilişkin niteliklerin geliştirilmesine de katkı sağlandığı görülmektedir.

Teknolojik gelişmelerin öngörülemez bir ilerleme içinde olduğu ve bilginin hızla arttığı bir ortamda bilginin geliştirilmesi ve üretimi büyük önem arz etmektedir. Özellikle 18. yüzyıldan sonra bu alanlarda geometrik artış büyük bir hızla devam etmektedir. Günümüz dünyasında bilgiye sahip olan ülkeler eğitim, teknoloji, ekonomi, sanat, kültür, politika vb. gibi her konuda güçlüdür. Bu anlamda bilginin üretilmesi, öğretilmesi ve yayılmasında eğitim sistemine büyük görevler düşmektedir (Karakütük, 2001). Ülkelerin amaçlarını gerçekleştirmesinde lisansüstü eğitimin önemi büyüktür. Lisansüstü eğitim yükseköğretime, kamu ve sanayi sektörünün çeşitli hizmet alanlarına yüksek nitelikli insan gücü yetiştirmenin yanı sıra, ülke sorunlarını çözmeye, kalkınma için gerekli teknolojiyi üretmeye yönelik araştırmaların yapılmasını sağlar (Karakütük, 1989: 506). Lisansüstü eğitim, Toplumun gereksinim duyduğu yüksek nitelikli insan gücünü yetiştirmekte faydalı bir programdır. Sözer'e (1991) göre, yetiştirilen insan gücünün niteliği, öğretmenin niteliği ve tutumları ile yakından ilgilidir ve hatta özdeş durumundadır. Öğrenci niteliklerinin yükseltilmesi isteniyorsa; onları yetiştiren öğretmenlerin öncelikle mesleki ve akademik açıdan tutumlarının pozitif yönde olması ve niteliklerinin yüksek olması gerekmektedir. Öğretmenlerin de, lisans sonrasında da iş başında eğitimini sürdürmelerinde uzmanlaşma, kendi niteliğini yükseltme, eğitim alanındaki yenilikleri takip etme ve sınıf ortamında bunları uygulayabilme bakımından lisansüstü eğitimin önemi büyüktür (Alabaş, 2011: 2897).

Yapılan araştırılmalarda lisansüstü eğitimin ülke kalkınmasında ve ülkenin gereksinim duyduğu yüksek nitelikli insan tipinin oluşmasında önemli bir rolü olduğu tespit edilmiştir. Lisansüstü eğitim örgün eğitimin bir basamağı haline gelmiştir. Karakütük (1989) lisansüstü eğitimin gelişmesini ve bugün yükseköğretim içinde önemli bir yer edinmesini şu nedenlere bağlamaktadır:

"1. II. Dünya savaşından sonra bilgi birikimi ve buluşların yeni uzmanlık alanlarının ortaya çıkarmasını zorunlu kılması.

2. Ülke kalkınmasında yüksek nitelikli insan gücüne ihtiyaç duyulması. 
3. Bilim ve teknolojinin hızlı biçimde gelişmesi nedeniyle mezun olduktan sonra edilinen bilgilerin yeterli olmaması ve bu konuda lisansüstü öğrenimin önemli rol üstlenmesi.

4. Temel eğitim süresinin uzaması ve çağ nüfusunun artışının okullaşmanın artışını sağlaması ve beraberinde gelen yüksek öğretimdeki okullaşmanın artarak öğretim üyesine duyulan ihtiyacın artması.

\section{Araştırma etkinliklerinin üniversitelerin işlevleri arasına girmesi."}

Yukarıdaki nedenleri incelendiğimizde bu durumun günümüzde de geçerli olduğu ve lisansüstü eğitimin öncelikli amacının akademisyen yetiştirme ve bilimsel alanda gelişmelerin sağlaması olduğu anlaşılmaktadır. Bunun yanı sıra nitelikli insan sayısındaki artış lisansüstü eğitimin doğal bir süreci haline gelmektedir. Eğitim kurumlarında iyi yetiştirilen öğretmenlerinin daha verimli ve etkin çalışması, gelecek kuşakları daha iyi yetiştirmesi farklı alanlarda bilgili ve nitelikli kişilerin sayısının artmasında önem arz etmektedir. Bu bilgiler doğrultusunda, sağlanan nitelik artışı ile daha verimli bir mesleki uygulama sağlayabilme ve daha kaliteli kurumlar tarafından tercih edilirliğin artışı düşüncesi lisansüstü eğitimin tercih edilmesinde önemli bir yer almaktadır. Tüm bu bilgiler ışığında öğretmen adaylarının ve öğretmenlerin lisansüstü eğitimi tercih etme durumlarının akademik düzeyde ele alınarak incelenmesi yararlı olacaktır. Ayrıca etki ve verimliliğin artışı bireyin istekleri ile kurumsal amaç ve işlev arasında bir uyum bulunmasını gerekli kılmaktadır (Erkılıç, 2007).

Lisansüstü eğitimin işlevleri incelendiğinde ise üniversitelerin işlevleri ile paralellik gösterdiği ortaya çıkmaktadır. Arııı'ya (1997) göre, bu işlevler; bilim ve sanat üretmek, toplumsal sorunları doğru algılamak, sorunlara çözüm önerileri geliştirmek ve üst düzey insan gücünün yetiştirilmesine katkıda bulunmak olarak ifade edilmiştir. Bu bağlamda eğitim işlevlerinin eğitim isteğini ne şekilde etkilediği Erkılıç (2007)'a ait çalışmada farklı açılardan ele alınmıştır.

Araştırma-Geliştirme, Erkılıç (2007)’ın çalışması kapsamında araştırma konusu edilen istemler bilim insanı olma isteği, bilimsel araştırma yapma isteği, teorik (kuramsal) konulara ilgi, bilimsel araştırma sürecini öğrenme isteği, bilimsel bakış açısı kazanma isteği ve akademik kariyer yapma isteği şeklinde ele alınmıştır.

Psiko-sosyal işlev, Bireyin toplumda yer edinmesi ve kendini gerçekleştirmeye yönelik çabaları, toplumsal statü kazanmak için üst eğitim kurumlarını tercih etme yönelimleri, diploma ve sertifika ile etiketlendirilme gereksinimi gibi istemler bu boyuta özgü kimi beklentilerdir (Bilgiseven, 1992: 29-30; Schaefer ve Lamm 1995: 456-457). Erkılıç (2007)'ın çalışmasında lisansüstü eğitimin özellikleri kapsamında söz konusu edilen istemler, askerlik erteleme-yaşama atılmayı geciktirme, bir gruba üye olma gereksinimini doyurma, sosyal statüsü yüksek iş bulma isteği, üniversitede akademisyen olma isteği, sosyal çevre geliştirme isteği, toplumda kabul görme gereksinimi, serbest (boş) zamanlarımı değerlendirme ve kendini gerçekleştirme isteği şeklinde ele alınmıştır.

Sosyo-ekonomik boyuttaki işlevler ile eğitime bireyin yaşamı sürdürebilmesi için iş, meslek edindirmeye yönelik ekonomik kazanım odaklı davranışların kazandırılması amaçlanır. Bu kapsamda eğitim, bireylere iş ve meslek için gereksinilen becerilerin kazandırılmasını amaçlar böylece eğitim sosyal hareketliliğe olanak sağlar (Hess vd., 1982: 374-375; Akt. Erkılıç, 2007). Genelde işlevselci kuram tarafından ileri sürülen görüşe göre eğitim düzeyi yükseldikçe bireyin geliri artış gösterir (Thio 1989: 344; Akt. Erkılıç, 2007). Erkılıç (2007)'ın çalışması kapsamında araştırma konusu edilen istemler, iş güvenliğini sağlama isteği, işte atanma olanaklarını genişletme etkeni, işte yükselme olanaklarını genişletme etkeni, iş bulma olanaklarını genişletme isteği ve daha iyi koşullarda iş bulma isteği şeklinde ele alınmıştır.

Bu konu ile ilgili yapılan çalışmalarda, lisans programlarından sonra verilen yüksek lisans ve doktora programları öğretmenlik mesleğinin daha nitelikli hale gelmesinde oldukça etkili olduğu belirtilmiştir. YÖK'ün de (2007) belirttiği gibi, öğretmenlik mesleği kendine özgü ilke ve uygulama yöntemleriyle profesyonel statüde bir meslektir. Bundan dolayı öğretmen yetiştirmenin her şeyden önce sağlıkı bir sisteme dayandırıması ve bu mesleğin lisansüstü eğitim imkânlarından daha fazla yararlanılması gerekir. Her öğretmen adayı geleceğine güvenli bakabilmesi için mesleki ve akademik anlamda yeterli 
donanıma sahip olması gerekmektedir. Sayın'a (2005) göre, lisans programlarından sonra verilen lisansüstü eğitim programları bireylerin hem mesleki hemde akademik anlamda üst noktaya ulaşmasında oldukça etkili olmaktadır. Bu nedenle öğretmen adaylarının lisansüstü eğitim tutumlarının ne olduğunu ortaya koymak önemli görülmektedir.

\subsection{Amaç}

Bu araştırmanın amacı, fen bilgisi öğretmen adaylarının lisansüstü eğitime ilişkin tutumlarının cinsiyet, mezun olunan lise türü, aile gelir durumu, sınıf düzeyi, anne ve babanın öğrenim durumu değişkenleri açısından incelenmesidir.

\subsection{Problem}

Bu araştırma doğrultusunda aşağıda yer alan alt problemler incelenmiştir.

1. Fen bilgisi öğretmen adaylarının lisansüstü eğitime yönelik tutumları cinsiyetlerine göre farklılık göstermekte midir?

2. Fen bilgisi öğretmen adaylarının lisansüstü eğitime yönelik tutumları sınıf düzeylerine göre farklılık göstermekte midir?

3. Fen bilgisi öğretmen adaylarının lisansüstü eğitime yönelik tutumları aylık gelir durumlarına göre farklılık göstermekte midir?

4. Fen bilgisi öğretmen adaylarının lisansüstü eğitime yönelik tutumları mezun oldukları lise türüne göre farklılık göstermekte midir?

5. Fen bilgisi öğretmen adaylarının lisansüstü eğitime yönelik tutumları anne eğitim durumlarına göre farklılık göstermekte midir?

6. Fen bilgisi öğretmen adaylarının lisansüstü eğitime yönelik tutumları baba eğitim durumlarına göre farklılık göstermekte midir?

\section{YÖNTEM}

Bu araştırmada nicel araştırma yöntemlerinden tarama yöntemi kullanılmıştır. Bir konuya ya da olaya ilişkin katıımcıların görüşlerinin ya da ilgi, beceri, yetenek, tutum vb. özelliklerinin belirlendiği genellikle diğer araştırmalara göre görece daha büyük örneklemler üzerinde yapılan araştırmalara tarama araştırmaları denir. (Büyüköztürk, Akgün, Demirel, Karadeniz, ve Kılıç, 2014).

\section{1 Çalışma Grubu}

Araştırmanın örneklemini iki farklı devlet üniversitesinin eğitim fakültesinde fen bilgisi öğretmenliği programında birinci, ikinci, üçüncü ve dördüncü sınıflarda öğrenim görmekte olan 235 öğrenci oluşturmaktadır. Araştırma grubundaki öğretmen adaylarının 201'ü (\%85.5) kadın ve 34'i (14.5) erkektir. Araştırmanın çalışma grubunu oluşturan fen bilgisi öğretmen adaylarının öğrenim gördükleri sınıf düzeyine göre dağılımı, birinci sınıftan 54 (\%23.0), ikinci sınıftan 57 (\%24.3), üçünü sınıftan 76 (\%32.3) ve dördünücü sınıftan 48 (\%20.4) öğretmen adayı şeklindedir.

\subsection{Veri Toplama Yöntemi}

Araştırma verilerinin toplanmasında İzgi (2016) tarafından geliştirilen Lisansüstü Eğitime illişkin Tutum Ölçeği'nden yararlanılııştır. Veri toplama aracı iki bölümden oluşmaktadır. 1. bölümde öğretmen adaylarının demografik özelliklerine ilişkin 6 soru, 2. bölümde ise lisansüstü eğitime ilişkin tutumu ölçmek amacıyla hazırlanmış $5^{\prime}$ i ters maddde olmak üzere toplam 30 madde bulunmaktadır. Ters maddeler 5'den 1'e, diğer maddeler ise 1'den 5'e puanlanmıştır. Ölçekten en az 30, en fazla 150 puan alınabilmektedir. Tutumlar, "tamamen katılıyorum, katılıyorum, kararsızım, katılmıyorum, hiç katılmıyorum" şeklinde beşli likert tipinde derecelendirilmiştir. Bu derecelendirmenin sınırları İzgi (2016) tarafından ortalaması 3'ten küçük ise düşük, 3'e eşit ise orta, 3'ten büyük ise yüksek tutuma sahip olarak belirlenmiştir. Lisansüstü Tutum Ölçeği'nin güvenirliğinin tespit edilmesi için Cronbach's Alpha değeri hesaplanmıştır. İzgi (2016) tarafından bulunan Cronbach's Alpha değeri .859'dur. Genel 
olarak güvenirlik katsayısı .70 ve üzerinde olan ölçeklerin güvenilir olduğu kabul edilmektedir (Büyüköztürk, 2014). Bu değerler ölçeğin güvenirliğinin yüksek düzeyde olduğunu göstermektedir.

\subsection{Verilerin Analizi}

Ölçme aracı ile elde edilen veriler SPSS 20 paket programı kullanılarak analiz edilmiştir. Ölçeğin toplam puanının sınıf düzeyi, mezun olunan lise türü, aile gelir durumu, anne öğrenim durumu ve baba öğrenim durumu ile karşılaştırılmasında tek faktörlü varyans analizi, cinsiyet ile karşılaştırılmasında ise bağımsız örneklem t-testi uygulanmıştır.

\section{BULGULAR}

Tablo 1. Fen Bilgisi Öğretmen Adaylarına Ait Lisansüstü Eğitime Illişkin Tutum Puanlarının Betimsel İstatistikleri

\begin{tabular}{ccccc}
\hline $\mathrm{N}$ & $\overline{\mathrm{X}}$ & ss & Çarpıklık & Basıklık \\
\hline 235 & 3.861 & .398 & .081 & -.332
\end{tabular}

Tablo 1'de yer alan değerlere bakıldığı zaman grubun ortalamasının 3,8609 olduğu görülmüştür. Bu değer İzgi (2016) tarafından belirlenmiş sınırlara göre grubun yüksek tutuma sahip olduğunu göstermektedir ( $x>3$, yüksek tutum).

3.1. Birinci Alt Probleme iliş̧kin Bulgular: Fen bilgisi öğretmen adaylarının lisansüstü eğitime yönelik tutumları cinsiyetlerine göre farklılık göstermekte midir?

Araştırmanın birinci alt problemi olan "Fen bilgisi öğretmen adaylarının lisansüstü eğitime yönelik tutumları cinsiyetlerine göre farklılık göstermekte midir?" sorusuna ilişkin elde edilen bulgulara Tablo'1 de yer verilmiştir.

Tablo 2. Fen Bilgisi Öğretmen Adaylarının Cinsiyete Göre Lisansüstü Eğitime Ilişkin Tutumları

\begin{tabular}{lcccccc}
\hline Cinsiyet & $\mathrm{N}$ & $\overline{\mathrm{X}}$ & ss & sd & $\mathrm{t}$ & $\mathrm{p}$ \\
\hline Kadın & 201 & 3.873 & .388 & 236 & .877 & .250 \\
Erkek & 34 & 3.789 & .454 & & &
\end{tabular}

Fen bilgisi öğretmen adaylarının lisansüstü eğitime yönelik tutumları cinsiyete göre anlamlı bir farklııı göstermemektedir, $\mathrm{t}(235)=.877, \mathrm{p}>$.01. Kadın öğretmen adaylarının lisansüstü eğitime yönelik tutumları ( $\overline{\mathrm{X}}=3.873)$, erkek öğretmen adaylarına ( $\overline{\mathrm{X}}=3.789)$ göre daha olumludur. Bu bulgu, lisansüstü eğitime yönelik tutumlar ile cinsiyet arasında anlamlı bir ilişkinin olmadı̆̆ı şeklinde de yorumlanabilir.

3.2. İkinci Alt Probleme İlişkin Bulgular: Fen bilgisi öğretmen adaylarının lisansüstü eğitime yönelik tutumları sınıf düzeylerine göre farklılık göstermekte midir?

Araştırmanın ikinci alt problemi olan "Fen bilgisi öğretmen adaylarının lisansüstü eğitime yönelik tutumları sınıf düzeylerine göre farklılık göstermekte midir?" sorusuna ilişkin elde edilen bulgulara Tablo 3'de yer verilmiştir.

Tablo 3. Öğretmen Adaylarının Tutumlarının Sınıf Düzeyine Yönelik Betimsel Istatistikleri

\begin{tabular}{lccc}
\hline Sınıf Düzeyi & $\bar{X}$ & $N$ & ss \\
\hline 1.Sınıf & 3.823 & 54 & .351 \\
2.Sınıf & 3.870 & 57 & .413 \\
3.Sınıf & 3.857 & 76 & .390 \\
4.Sınıf & 3.898 & 48 & .449 \\
Toplam & 3.861 & 235 & .398 \\
\hline
\end{tabular}

Analiz sonuçları, öğretmen adaylarının lisansüstü eğitime yönelik tutumları ile öğrenim görmekte oldukları sınıf düzeyleri arasında anlamlı bir farklılık olmadığını göstermektedir, $F(3,232)=.190$, $p>$.01. Sınıf düzeylerine göre grupların tutum ortalamalarına bakıldığında, 4. Sınıfların $(\bar{X}=3.898)$ en 
yüksek tutum ortalamasına, 1 . Sınıfların $(\bar{X}=3.823)$ ise en düşük tutum ortalamasına sahip oldukları görülmektedir.

Tablo 4. Fen Bilgisi Öğretmen Adaylarının Sınıf Düzeylerine Göre Lisansüstü Eğitime Yönelik Tutumları

\begin{tabular}{lccccc}
\hline $\begin{array}{l}\text { Varyansın } \\
\text { Kaynağı }\end{array}$ & Kareler toplamı & sd & Kareler ortalaması & $F$ & $\mathrm{p}$ \\
\hline Gruplar arası & .084 & 3 & .028 & .190 & .903 \\
Gruplar içi & 34.514 & 232 & .147 & & \\
Toplam & 34.598 & 235 & & &
\end{tabular}

Tablo 4'te yer alan bilgilere göre fen bilgisi öğretmen adaylarının lisansüstü eğitime yönelik tutum ortalamalarının sınıf düzeylerine göre istatistiksel olarak farklılaşmadığı görülmektedir ( $p>.05$ ).

3.3. Üçüncü Alt Probleme iliş̧kin Bulgular: Fen bilgisi öğretmen adaylarının lisansüstü eğitime yönelik tutumları aylık gelir durumlarına göre farklılık göstermekte midir?

Araştırmanının üçüncü alt problemi olan "Fen bilgisi öğretmen adaylarının lisansüstü eğitime yönelik tutumları aylık gelir durumlarına göre farklıık göstermekte midir?" sorusuna ilişkin elde edilen bulgulara Tablo 5 'te yer verilmiştir.

Tablo 5. Öğretmen Adaylarının Tutumlarının Aylık Gelir Durumuna Yönelik Betimsel Istatistikleri

\begin{tabular}{lccc}
\hline Aylık Gelir Durumu & $\bar{X}$ & N & ss \\
\hline Asgari Ücret & 3.939 & 43 & .457 \\
Asgari Ücret-1600 & 3.845 & 32 & .399 \\
$1601-1800$ & 3.887 & 57 & .393 \\
$1801-3600$ & 3.826 & 76 & .355 \\
3601 ve üstü & 3.794 & 27 & .429 \\
Toplam & 3.861 & 235 & .398
\end{tabular}

Analiz sonuçları, öğretmen adaylarının lisansüstü eğitime yönelik tutumları ile aylık gelir durumları arasında anlamlı bir farklılık olmadığını göstermektedir, $F(3,232)=.798, p>, 01$. Aylık gelir durumlarına göre grupların tutum ortalamalarına bakıldığında, aylık geliri asari ücret olanların ( $\bar{X}=3.939)$ en yüksek tutum ortalamasına, 3601 tl ve üzeri olanların ( $\bar{X}=3.794)$ ise en düşük tutum ortalamasına sahip oldukları görülmektedir.

Tablo 6. Fen Bilgisi Öğretmen Adaylarının Aylık Gelir Durumlarına Göre Lisansüstü Eğitime Yönelik Tutumları

\begin{tabular}{lccccc}
\hline $\begin{array}{l}\text { Varyansın } \\
\text { Kaynağı }\end{array}$ & $\begin{array}{c}\text { Kareler } \\
\text { toplamı }\end{array}$ & sd & Kareler ortalaması & $\mathrm{F}$ & $\mathrm{p}$ \\
\hline Gruplar arası & .468 & 3 & .117 & .798 & .528 \\
Gruplar içi & 34.130 & 232 & .146 & & \\
Toplam & 34.598 & 235 & & & \\
\hline
\end{tabular}

Elde edilen sonuçlara göre gruplar arasında istatistiksel olarak farklılık olmadığı sonucuna varılmıştır (p>.01).

3.4. Dördüncü Alt Probleme ilişkin Bulgular: Fen bilgisi öğretmen adaylarının lisansüstü eğitime yönelik tutumları mezun oldukları lise türüne göre farklılık göstermekte midir?

Araştırmanının dördüncü alt problemi olan "Fen bilgisi öğretmen adaylarının lisansüstü eğitime yönelik tutumları mezun oldukları lise türüne göre farklılık göstermekte midir?" sorusuna ilişkin elde edilen bulgulara Tablo 7'de yer verilmiştir. 
Tablo 7. Öğretmen Adaylarının Tutumlarının Mezun Olunan Lise Türüne Göre Betimsel Istatistikleri

\begin{tabular}{lccc}
\hline Mezun Olunan Lise Türü & $\overline{\mathrm{X}}$ & $\mathrm{N}$ & ss \\
\hline Düz Lise & 3.871 & 100 & .044 \\
Anadolu Lisesi & 3.835 & 100 & .375 \\
Öğretmen Lisesi & 3.939 & 6 & .420 \\
Meslek Lisesi & 3.949 & 11 & .319 \\
İmam Hatip Lisesi & 3.908 & 9 & .332 \\
Toplam & 3.861 & 235 & .398
\end{tabular}

Analiz sonuçları, öğretmen adaylarının lisansüstü eğitime yönelik tutumları ile mezun oldukları lise türleri arasında anlamlı bir farklılık olmadığını göstermektedir, $F(4,231)=.382$, p>.01. Mezun oldukları lise türlerine göre grupların tutum ortalamalarına bakıldığında, meslek liselerinden mezun olanların ( $\bar{X}=3.949)$ en yüksek tutum ortalamasına, anadolu liselerinden mezun olanların ( $\bar{X}=3.835)$ ise en düşük tutum ortalamasına sahip oldukları görülmektedir.

Tablo 8. Fen Bilgisi Öğretmen Adaylarının Mezun Olunan Lise Türüne Göre Lisansüstü Eğitime Yönelik Tutumları

\begin{tabular}{llllll}
\hline Varyansın Kaynağı & Kareler toplamı & sd & Kareler ortalaması & F & p \\
\hline Gruplar arası & .225 & 4 & .056 & .382 & .822 \\
Gruplar içi & 34.373 & 231 & .148 & & \\
Toplam & 34.598 & 235 & & & \\
\hline
\end{tabular}

Elde edilen sonuçlara göre gruplar arasında istatististiksel olarak farklılık olmadığı sonucuna varılmıştır ( $p>01$ ).

\subsection{Beşinci Alt Probleme illişkin Bulgular: Fen bilgisi öğretmen adaylarının lisansüstü eğitime yönelik tutumları anne eğitim durumlarına göre farklılık göstermekte midir?}

Araştırmanının beşinci alt problemi olan "Fen bilgisi öğretmen adaylarının lisansüstü eğitime yönelik tutumları anne eğitim durumlarına göre farklılık göstermekte midir?" sorusuna ilişkin elde edilen bulgulara Tablo 9'da yer verilmiştir.

Tablo 9. Öğretmen Adaylarının Tutumlarının Anne Öğrenim Durumuna Göre Betimsel Istatistikleri

\begin{tabular}{lccc}
\hline Anne Öğrenim Durumu & $\overline{\mathrm{X}}$ & $\mathrm{N}$ & ss \\
\hline Okuryazar değil & 3.884 & 38 & .479 \\
ilkokul & 3.856 & 115 & .395 \\
Ortaokul & 3.868 & 47 & .388 \\
Lise & 3.829 & 29 & .347 \\
Lisans & 3.900 & 6 & .324 \\
Toplam & 3.861 & 235 & .398
\end{tabular}

Analiz sonuçları, öğretmen adaylarının lisansüstü eğitime yönelik tutumları ile annelerinin öğrenim durumları arasında anlamlı bir farklıık olmadığını göstermektedir, $F(4,231)=.229, p>.01$. Anne öğrenim durumlarına göre grupların tutum ortalamalarına bakıldığında, annesi lisans mezunu olanların ( $\bar{X}=3.900)$ en yüksek tutum ortalamasına, annesi lise mezunu olanların ( $\bar{X}=3.829)$ ise en düşük tutum ortalamasına sahip oldukları görülmektedir. 
Tablo 10. Fen Bilgisi Öğretmen Adaylarının Anne Öğrenim Durumuna Göre Lisansüstü Eğitime Yönelik Tutumları

\begin{tabular}{llllll}
\hline Varyansın Kaynağı & Kareler toplamı & Sd & Kareler ortalaması & $F$ & $p$ \\
\hline Gruplar arası & .136 & 4 & .034 & .229 & .922 \\
Gruplar içi & 34.462 & 231 & .148 & & \\
Toplam & 34.598 & 235 & & & \\
\hline
\end{tabular}

Elde edilen sonuçlara göre gruplar arasında istatististiksel olarak farklılık olmadığı sonucuna varılmıştır ( $p>.01)$.

\subsection{Altıncı Alt Probleme iliş̧kin Bulgular: Fen bilgisi öğretmen adaylarının lisansüstü eğitime yönelik tutumları baba eğitim durumlarına göre farklılık göstermekte midir?}

Araştırmanının altıncı alt problemi olan "Fen bilgisi öğretmen adaylarının lisansüstü eğitime yönelik tutumları baba eğitim durumlarına göre farklılık göstermekte midir?" sorusuna ilişkin elde edilen bulgulara Tablo 11'de yer verilmiştir.

Tablo 11. Öğretmen Adaylarının Tutumlarının Baba Öğrenim Durumuna Göre Betimsel Istatistikleri

\begin{tabular}{lccc}
\hline Baba Öğrenim Durumu & $\overline{\mathrm{X}}$ & $\mathrm{N}$ & $\mathrm{S}$ \\
\hline Okuryazar değil & 3.517 & 2 & .417 \\
ilkokul & 3.840 & 79 & .049 \\
Ortaokul & 3.947 & 62 & .052 \\
Lise & 3.824 & 54 & .048 \\
Lisans & 3.814 & 36 & .058 \\
Lisansüstü & 4.200 & 2 & .067 \\
Toplam & 3.861 & 235 & .026
\end{tabular}

Analiz sonuçları, öğretmen adaylarının lisansüstü eğitime yönelik tutumları ile babalarının öğrenim durumları arasında anlamlı bir farklılık olmadığını göstermektedir, $F(5,230)=1,110, p>, 01$. Baba öğrenim durumlarına göre grupların tutum ortalamalarına bakıldığında, babası lisansüstü mezunu olanların $(\bar{X}=4,200)$ en yüksek tutum ortalamasına, babası okuryazar olmayanların $(\bar{X}=3,517)$ ise en düşük tutum orlamasına sahip oldukları görülmektedir.

Tablo12. Fen Bilgisi Öğretmen Adaylarının Baba Öğrenim Durumuna Göre Lisansüstü Eğitime Yönelik Tutumları

\begin{tabular}{lccccc}
\hline Varyansın Kaynağı & Kareler toplamı & sd & Kareler ortalaması & $F$ & $\mathrm{p}$ \\
\hline Gruplar arası & .808 & 5 & .162 & 1.110 & .356 \\
Gruplar içi & 33.790 & 230 & .146 & & \\
Toplam & 34.598 & 235 & & & \\
\hline
\end{tabular}

Elde edilen sonuçlara göre gruplar arasında istatististiksel olarak farklılık olmadığı sonucuna varılmıştır ( $p>.01)$.

\section{SONUÇ VE TARTIŞMA}

Bu çalışmada fen bilgisi öğretmen adaylarının sosyo-kültürel özelliklerinin lisansüstü eğitime ilişkin tutumları üzerindeki etkisi incelenmiştir. Araştırma sonucunda fen bilgisi öğretmen adaylarının lisansüstü eğitime yönelik tutumlarının yüksek düzeyde olduğu görülmüştür. Erkılıç (2007) tarafından yapılan çalışmada da öğretmen adaylarının lisansüstü eğitim yapmaya yönelik istekliliklerinin yüksek olduğu sonucu elde edilmiştir. İzgi (2016) tarafından yapılan çalışmada da benzer sonuçlara ulaşıımıştır. Bu çalışmada kadınların lisansüstü eğitime ilişkin tutum ölçeğinden 
elde edilen tutum puanı ortalamalarının erkeklere oranla daha yüksek olduğu ancak anlamlı bir farklıık olmadığı sonucuna ulaşılmıştır. Benzer bir şekilde İlhan, Sünkür-Öner ve Yılmaz (2012) tarafından yapılan çalışmada da ilköğretim öğretmen adaylarının lisansüstü eğitime yönelik tutumlarının yüksek olduğu, kadınların erkeklere oranla daha yüksek tutuma sahip olduğu ancak anlamlı bir farklııı olmadığı sonucuna ulaşılmıştır.

Sınıf düzeyi değişkeninin lisansüstü eğitime yönelik tutum üzerindeki etkisi incelendiğinde birinci sınıfların en düşük dördüncü sınıfların ise en yüksek tutuma sahip olduğu sonucuna ulaşılmıştır. Bu durum öğrencilerin eğitim aldıkları süre boyunca tutumlarının azda olsa arttığını göstermektedir. Bunun yanında gruplar arasında anlamlı bir fark olmadığı görülmektedir. Ancak, ilhan vd., (2012) göre ilköğretim öğretmen adaylarının lisansüstü eğitimin işlevine yönelik tutumları, sınıf ve anabilim dalı değişkenleri açısından anlamlı farklılık göstermektedir. Ören, Yılmaz ve Güçlü (2012) çalışmalarında sınıf düzeyi arttıkça lisansüstü eğitime yönelik ilginin arttı̆̆ı sonucuna ulaşmışlar ve durumun bilgilenme düzeyinin artması, geleceğe yönelik planlamaların daha fazla önemsenmesi, atanamamaktan korkarak başka seçenek oluşturmak istenmesi ve kişisel ya da mesleki gelişimi ile lisansüstü eğitim arasında ilişkilendirme yaparak gelişimin arttırılmasının istemesi gibi nedenlerle ilişkili olabileceğini öne sürmüşlerdir.

Çalışma grubunda yer alan fen bilgisi öğretmen adayları, aile aylık gelir durumlarına göre gruplarındırıldığında frekanslarının birbirine yakın olduğu ve buna bakılarak ekonomik düzeyin öğretmenlik mesleği seçiminde etkili olmadığı yorumu yapılabilir. Bunun yanında aylık gelir durumunun lisansüstü eğitime yönelik tutum üzerinde etkiliği olmadığı görülmektedir. Ancak, Erkılıç (2007) çalışmasında, sosyo-ekonomik boyuttaki etmenlerin lisansüstü eğitim yapma isteğini, Okulöncesi, İşitme Engelliler ve Fen Bilgisi öğretmenliği programları öğrencilerinde orta derecede; Sınıf, Matematik, İngilizce, Fransızca, Almanca, Zihin Engelliler ve Bilgisayar öğretmenliği programları öğrencilerinde çok etkilediğini, Sosyal Bilgiler, Resim -iş ile Beden Eğitimi ve Spor öğretmenliği öğrencilerinde ise pek çok etkilediğini saptamıştır.

Araştırmada cinsiyet değişkenine göre adayların \%85.5'inin kadın, \%14.5'inin erkek öğrencilerden oluştuğu görülmüştür. Bu sonuca bakarak fen bilgisi öğretmenliğinin kadınların erkeklere oranlara daha fazla tercih ettiği söylenebilir. Çil'e (2000) göre, öğretmenlik mesleğinin bir bayan mesleği olarak görüldüğüne dair yaygın bir görüş vardır. Mezun olunan lise türüne bakıldığı zaman ise öğretmen adaylarının \%42.55'inin düz lise, \%42.55'inin ise anadolu liselerinden geldiği görülmektedir. Öğretmen liselerinden gelen öğrencilerin ise örneklemin \%2.55'ini oluşturuduğu görülmektedir. Bu değerlere bakılarak öğretmen liseleri öğrencilerinin fen bilgisi öğretmenliğini çok fazla tercih etmediği sonucuna varılabilir. Köksalan (2010) tarafından yapılan çalışmada da öğretmen adaylarının büyük çoğunluğunun genel liselerden geldiği görülmektedir.

Yapılan çalışmada baba öğrenim durumunun tutum üzerinde etkili olmadığı görülmektedir. Ünal (2010)'ın çalışmasında benzer bir sonuca ulaşılımıştır.

Çalışmadan elde edilen sonuçlar diğer birçok çalışmaya benzer şekilde genel olarak öğretmen adaylarının lisansüstü eğitim alma isteklerinin yüksek olduğunu göstermiş olup bu olumlu bir sonuçtur. Lisansüstü eğitimin amacl, bir bilgi alanında derinlemesine çalışarak uzmanlaşmış, üst seviyede bilgi ve etkinliğe sahip, araştırmacı, yaratıcı, araştırma yoluyla bilgiye katkıda bulunacak, bilim üretecek ve yayabilecek, etik değerlere saygıll, sorunlara akılcı yöntemlerle çözüm üretebilen, bilimsel bakış açısı kazanmış, grup çalışması ve disiplinler arası çalışmalara katılmaya istekli, nitelikli çalışmalar üretebilen, gelişen toplumun ihtiyaçlarını karşılayacak, ülke kalkınmasında gereksinim duyulan yüksek nitelikli insan tipinin yetiştirilmesidir. Öğretmenlerin ve öğretmen adaylarının yüksek lisans eğitimi alarak sayılan bu niteliklere olabildiğince fazla sahip olarak kendi niteliklerini yükseltme, eğitim alanındaki yenilikleri takip etme ve sınıf ortamında bunları uygulayarak öğrencilerine çok daha fazla katkı sağlayacaklardır. Bu bağlamda öğretmen eğitiminin geliştirilmesi yanında, öğretmenlerin kendi alanlardaki kariyer gelişimlerinin de desteklenmesi tüm toplum kesimlerinin yararına olaaktır. 


\section{1 Öneriler}

Araştırmanın örneklemini genişleterek evrene daha yakın bir grup ile çalışılabilir. Lisansüstü eğitime yönelik tutum üzerinde etkili olan ve bu araştırmada yer almayan değişkenleri belirleyip, bu değişkenlerin tutum üzerindeki etkilerinin inceleneceği çalışmalar yürütülebilir. Tutumların yüksek çıkması sebebiyle, öğrencilere lisansüstü eğitim ile ilgili bilgilerin verileceği eğitimler düzenlenebilir, lisansüstü eğitim düzeyinde öğrencilere verilen burs imkânları arttırılabilir, eğitim alanında lisansüstü öğrenimi gören kişilere bu eğitimin bitiminde devlete bağı okullarda çalışmaları durumunda çeşitli desteklerin sağlanması ile motivasyonlarının daha artıııması ve öğretmen adaylarının lisansüstü eğitim programlarına katılması ile hem güçlü ve nitelikli akademik ortamların oluşmasına hem de daha nitelikli öğretmenlerin yetiştirilmesine katkı sağlanacağı düşünülmektedir.

\section{Kaynakça}

Alabaş, R., Kamer, T. ve Polat, Ü. (2012). Öğretmenlerin kariyer gelişimlerinde lisansüstü eğitim: tercih sebepleri ve süreçte karşılaştıkları sorunlar. E-international Journal of Educational Research, 3, 89107.

Arıcı, H. (1997). Bilim Insanı Yetiştirme: Lisansüstü Eğitim ve Sorunları. Ankara: Türkiye Bilimler Akademisi Bilimsel Tooplantı Serileri 7, Bilim İnsanı Yetiştirme, Lisansüstü Eğitim.

Bilgiseven, A. K. (1992). Eğitim sosyolojisi. İstanbul: Filiz Kitabevi.

Bülbül, T. (2003). Ankara Üniversitesi Eğitim Bilimleri Fakültesinde Görev Yapan Öğretim Üyelerinin Lisansüstü Öğretime Öğrenci Seçme Sürecine İlişkin Görüşleri. Ankara Üniversitesi Eğitim Bilimleri Fakültesi Dergisi, 36 (1-2), 167-174.

Büyüköztürk, Ş., Kılıç Çakmak, E., Akgün, Ö. E., Karadeniz, ş. ve Demirel, F. (2014). Bilimsel Araştırma Yöntemleri (17. Baskı). Ankara: PegemA Yayıncılık.

Çapa, Y. ve Çil, N. (2000). Öğretmen Adaylarının Öğretmenlik Mesleğine Yönelik Tutumlarının Farklı Değişkenler Açısından İncelenmesi. Hacettepe Üniversitesi Eğitim Fakültesi Dergisi, 18, 69-73.

Erkılıç, T. A. (2007). Öğretmen adaylarının lisansüstü eğitim istekliliklerini etkileyen etmenler (Eskişehir örneği). GAU Journal of Social \&Applied Sciences, 3(5), 46-72.

Güven, İ, ve Tunç, B. (2007). Lisansüstü Öğrencilerinin Akademik Sorunları (Ankara Üniversitesi Eğitim Bilimleri Enstitüsü Örneği). Millî Ĕgitim, 173,157-172.

İlhan, M., Sünkür-Öner M. ve Yılmaz, F. (2012). İlköğretim öğretmen adaylarının lisansüstü eğitime yönelik tutumlarının incelenmesi (Dicle Üniversitesi Örneği). Mehmet Akif Ersoy Üniversitesi Ĕgitim Fakültesi Dergisi, 23, 22-42.

İzgi, S. (2016). Sosyal bilgiler öğretmenliği öğrencilerinin lisansüstü eğitime ilişkin tutumlarının bazı değişkenler açısından incelenmesi (Yüksek Lisans Tezi). Ulusal Tez Merkezinden ulaşılmıştır. (452182.)

Karakütük, K. (2001). Öğretim Üyesi ve Bilim Insanı Yetiştirme: Lisansüstü Öğretimin Planlanması. 2.Baskı, Ankara: Anı Yay.

Karakütük, K. (1989). Türkiye'de lisansüstü öğretim, sorunları ve çözüm önerileri. Ankara Üniversitesi Eğitim Bilimleri Fakültesi Dergisi, 22(1), 505-528.

Köksalan, B., i̇lter, İ., \& Görmez, E. (2010). Sinif Öğretmeni Adaylarinin Sosyo-Kültürel Özellikleri Ve Lisansüstü Eğitim İsteklilikleri Üzerine Bir Çalişma (Firat, Erzincan Ve İnönü Üniversitesi Sinif Öğretmenliği Abd Örneği). Ahi Evran Üniversitesi Kırşehir Eğitim Fakültesi Dergisi, 11(3), 277-299.

Oğuzkan, F. (1981). Eğitim Terimleri Sözlüğü. Ankara: Türk Dil Kurumu Yay.

Ören, F. Ş., Yılmaz, T. ve Güçlü, M. (2012). Öğretmen adaylarının lisansüstü eğitime yönelik görüşlerinin analizi. Eğitim ve Öğretim Araştırmaları Dergisi, 1(2), 189-201. 
Sayın, S. (2005). Öğretmen Adaylarının Öğretmenlik Mesleğine Karşı Tutumları ve Mesleki Benlik Saygıların Incelemesi. Eurasion Journal of Education Research, 19, 272, 281.

Sözer. E. (1991). Türk Üniversitelerinde Öğretmen Yetiştirme Sistemlerinin Öğretmenlik Davranışlarını kazandırma Yönünden Etkinliği. Eskişehir: Eskişehir Anadolu Ün. Basımevi.

Ünal, Ç. ve İlter, ì. (2010). Sınıf öğretmeni adaylarının lisansüstü eğitime olan tutumları (Fırat, Erzincan ve İnönü Üniversitesi Sınıf Öğretmenliği ABD Örneği). Atatürk Üniversitesi Sosyal Bilimler Enstitüsü Dergisi, 14(2), 1-18.

Varış, F. (1973). Türkiye'de Lisansüstü Eğitim. Ankara: Ankara Ün. Eğitim Bilimleri Yay.

YÖK (2016). YÖK Kanunun Mad. 2, Mad. 3, 2547 Resmî Gazete, Lisansüstü Eğitim ve Öğretim Yönetmeliği, Ankara.

YÖK/Dünya Bankası (2007). Öğretmen Yetiştirme ve Eğitim Fakülteleri Öğretmenin Üniversitede Yetiştirilmesinin Değerlendirilmesi (1982-2007). Ankara. 


\section{Extended Summary}

The number of individuals enrolling for undergraduate studies is increasing day by day in our country, some of these individuals are inclined to continue their graduate education. Many factors can be attributed to this trend. Gender, type of high school attended, family income, class level, parents' education level are variables thought to be affecting this tendency. Accordingly, the purpose of this study is to examine the attitudes of candidate science teachers' toward graduate education with regards to gender, type of high school attended, family income status, class level and education level of parents. The fundamental question of the research was " does the candidate science teachers' attitude towards graduate education differ according to their gender, type of high school they attended, family income, class level, fathers and mothers educational status?"

Quantitative research method was used in this study. The sample of this study consists of 235 students who are freshman, sophomore, junior and senior students in the departments of science education, education faculty at two different state universities. In the study group 201 (85.5\%) of the candidate science teachers were female, and 34 (14.5) were male. The distribution of candidate teachers in the study group according to their classes was as follows: $54(23 \%)$ freshman, $57(24.3 \%)$ sophomore, $76(32.3 \%)$ juniors, and $48(20.4 \%)$ seniors. The attitude toward education scale developed by İzi (2016) was used for collecting data in this study. The data summation tool consists of two parts. In the first part, there are 6 questions about the demographic characteristics of the candidate science teachers and in the second part, there are 5 negative and 25 positive questions that were prepared to measure their attitude towards graduate education. The positive statements were calculated from 5 to 1 and the negative statements from 1 to 5 . At least 30 and at most 150 points can be obtained from the scale.

The study data was collected as a result of applying the personal information form and attitude toward graduate studies scale to candidate science teachers. The data obtained with the assessment and evaluation tool was analyzed using the SPSS 20 packet program. One-factor variance analysis was used to compare the total score of the scale on the type of high school attended, family income, mother's education status, father's education status, and independent sample t-test was used for gender comparison.

As a first sub-problem, the effect of gender variable on attitude toward graduate education was examined. When the average of attitudes of male and female teacher candidates were examined, it was observed that the attitude towards graduate education does not differ according to gender. As a second sub-problem the research examined the question, "Does candidate science teachers' attitude toward graduate education differ according to their education level?". When the mean values obtained were examined, it was observed that freshman class had the lowest average and the senior class had the highest average but there was no significant difference between class levels. As a third sub-problem the research examined the question, "Does candidate science teachers' attitude toward graduate education differ according to monthly income?". When the average values of the attitudes of the groups were examined, it was observed that candidate teachers had high attitudes and there was no significant difference between the groups. As a fourth sub-problem the research examined the question, "Does candidate science teachers' attitudes toward graduate education differ according to the high school they attended?", it was observed that the majority of candidate science teachers graduate from General and Anatolian high schools. When we looked at the data obtained, it was seen that the attitudes of the groups were high and there was no significant difference between the groups. As a fifth sub-problem the research examined the question, "Does candidate science teachers' attitude toward graduate education differ according to their mothers' educational status?". When the data obtained was studied, it was observed the groups' means were close to one another, their attitudes were high and there was no significant difference between the groups. As a sixth sub-problem the research examined the question, "Does candidate science teachers' attitude toward graduate education differ according to their fathers' educational status?". 
When we looked at the means, it was observed that the highest mean belonged to the group with fathers who have attended graduate education and the lowest mean belonged to the group with fathers who are not literate but the averages of the groups were close to one another and there was no significant difference between them.

In this study the effects of candidate science teachers' socio-economic level on their attitude toward graduate education was examined. In the result of the study it was observed that the attitude of candidate science teachers was high. Even though females' attitude was proportionately high compared to males, it was not statistically significant. A similar result was attained in a study conducted by Ilhan (2012). In the study, it was observed female candidate science teachers occupied more space on the gender distribution compared to males. In a study conducted by Çil (2000) it was pointed out that there was widespread belief that teaching was a women's profession. In the study carried out it was indicated students who graduated from teacher high schools didn't highly prefer science teaching. In another study conducted by Köksalan (2010) it was observed that many of candidate teachers came from general high schools. When looking at the education level of parents, it can be seen that the mothers of the $16.2 \%$ candidate teachers were not literate in comparison only $0.9 \%$ of the fathers of the candidate teachers were not literates. This situation proves that girls' education didn't receive the needed importance in our recent past. In a similar study conducted it was observed that the education level of fathers did not have an effect on attitude. The same result was obtained in Unal (2010)'s study. 